\title{
Studies on Genetic Variability and Character Association in Linseed (Linum usitatissimum L.) Genotypes
}

\author{
Ashok Kumar Meena ${ }^{1 *}$, Sandhya Kulhari ${ }^{1}$, Manoj Kumar ${ }^{1}$, N. R. Koli ${ }^{1}$, Yamini Tak ${ }^{2}$, \\ Deepak Meena ${ }^{1}$ and Neetu Meena ${ }^{3}$
}

${ }^{1}$ Department of Genetics and plant breeding, ${ }^{2}$ Department of Biochemistry

College of Agriculture, Agriculture University, Kota, Rajasthan-324001

${ }^{3}$ Department of Nematology, Rajasthan College of Agriculture, MPAUT, Udaipur, College of Agriculture, Agriculture University, Kota, Rajasthan- 324001, India

*Corresponding author

\section{A B S T R A C T}

\section{Keywords}

Genetic variability, Heritability, Genetic advance,

Correlation coefficient, Path analysis

\section{Article Info}

Accepted:

22 June 2020

Available Online:

10 July 2020
A study was conducted to assess the induced genetic variability, interrelationship among yield components and their direct and indirect effect on yield. Thirty six genotypes of linseed (Linum usitatissimum L.) were evaluated in Randomized Complete Block Design with three replications. Substantial amount of genetic variations were observed with low influence of environment indicated consistence performance of the genotypes. GCV and PCV were highest for number of capsules per plant followed by number of primary branches per plant. Greater magnitude of heritability coupled with high to moderate genetic advance as per cent of mean was observed for number of capsules per plant, number of primary branches per plant, plant height, seed yield per plant and 1000 seed weight. Seed yield per plant had positive and significant correlation with plant height, number of capsules per plant 1000 seed weight and protein content, while highly correlate with number of capsules per plant. Path coefficient analysis revealed that number of capsules per plant has strong positive direct effect on seed yield per plant. Number of capsules per plant, number of primary branches per plant, 1000 seed weight and plant height were identified as important traits for selection in linseed breeding program.

\section{Introduction}

Linseed (Linum usitatissimum L.) is one of the most important Rabi oilseed crop after rapeseed and mustard. It originated in Mediterranean and the southwest Asian regions (Vavilov, 1935). Linseed is an annual herbaceous self-pollinated crop. It belongs to the order Malpighiales, genus Linum and family Linaceae. It is the richest source of vegetarian Omega-3 fatty acid and good source of protein, dietary fiber, lignin, flaxfiber and essential micronutrients. Although India ranks third in the world, productivity is low as the crop is generally grown as rainfed and area under linseed cultivation is continuously declining in the country. In India it occupies an area of 0.32 mha with a 
production of $0.17 \mathrm{mt}$ and productivity of 535 $\mathrm{Kg} / \mathrm{ha}$ (DAC \& FW, 2018). Whereas in Rajasthan it is cultivated on 0.04 mha area with production of $0.05 \mathrm{mt}$ production and productivity $1012 \mathrm{Kg} / \mathrm{ha}$ (Annual Report of AICRP on Linseed, 2017-18). In Kota region it occupied an area 1544 ha with production $1537 \mathrm{t}$ and productivity (760 kg/ha) (Annual Report of AICRP on Linseed, 2017-18).

The linseed crop has maintained its increasing trend in productivity while the area registered shows the declining trend resulting in stagnant production. Poor yield of linseed crop is attributed to non-availability of improved cultivars to suit the diverse agro climatic conditions. Hence, development of high yielding cultivars becomes the top most priority to overcome the poor yield levels (Leelavathi and Mogali, 2018).

Genetic variability studies offer better scope for selection and help in development of high yielding varieties. The magnitude of heritable variation in the traits studied has immense value in understanding the potential of the genotype for further breeding programme. Assessment of variability for yield and its component characters becomes absolutely essential before planning for an appropriate breeding strategy for genetic improvement. The inter-relationship between important yield components is best estimated by correlation coupled with path coefficient analysis. These techniques used in the breeding programme to exploit the yield potential for enhancing the productivity of the linseed and to develop high yielding improved varieties. Correlation is the mutual relationship between the variables, it aids in determining the most effective procedures for selection of superior genotypes. A path coefficient is a standardized, partial regression coefficient that measures the direct influence of one trait upon another trait and permits the separation of a correlation coefficient into components of direct and indirect effects for a set of a priori cause-andeffect interrelationships. To determine the direct and indirect effects of seed yield components on seed yield, it is essential to compute correlations of the yield components among themselves and with seed yield.

\section{Materials and Methods}

The present investigation was undertaken at Department of Genetics and Plant Breeding, College of Agriculture, Kota during Rabi 2019-2020. The site of experiment is at an elevation of about 271 meter $(889 \mathrm{ft})$ above mean sea level with $25.18^{\circ} \mathrm{N}$ latitude and $75.83^{\circ} \mathrm{E}$ longitude. The standard week wise meteorological data for the period of this investigation recorded at the Meteorological Observatory, ARS, Kota. In this experiment out of thirty-six including checks, each genotype was grown in $3 \mathrm{~m}$ long plot with plant to plant distance was maintained at 10 $\mathrm{cm}$ in Randomized Complete Block Design (RBD) with three replications during Rabi season, 2019-20. The analysis of variance for individual characters and for the character pairs respectively, were carried out using the mean values of each plot following the method given by Panse and Sukhatme (1985). The genotypic coefficient of variation (GCV) and phenotypic coefficient of variation (PCV) were computed, following Burton and Devane, (1953) method. Heritability in broad sense $h^{2}$ (broad sense) was calculated as a ratio of genotypic variance to phenotypic variance (Allard, 1960). The expected genetic advance under selection for the different characters was estimated as suggested by Johnson et al., (1955). To determine the degree of association of various characters with yield and also among the yield components, the correlation coefficients were calculated. The correlation was calculating using the formula given by fisher (1918). The direct and indirect effects were estimated 
using path coefficient analysis as suggested by Wright (1921) and elaborated by Dewey and $\mathrm{Lu}$ (1959).

\section{Results and Discussion}

The ultimate objective of most of the plant breeding programmes is to develop high yielding superior genotypes/lines better than existing ones through the manipulation of genetic constellation. Linseed (Linum usitatissimum L.) is an important Rabi oilseed crop grown in India and in other developing countries of the world. Looking to the above aspects, the present investigation was undertaken subject to different genetical studies viz., genetic variability, heritability and genetic advance. The results obtained from the present investigation are discussed below.

The analysis of variance indicated that the highly significant mean differences were observed for all the eleven characters under study viz., days to 50 per cent flowering, days to maturity, plant height $(\mathrm{cm})$, number of primary branches per plant, number of capsules per plant, number of seeds per capsule, 1000 seed weight $(\mathrm{g})$, harvest index $(\%)$, protein content $(\%)$, oil content $(\%)$, seed yield per plant (g) (Table-1), this studies supported by Bindra et al., (2016); Choudhary et al., (2017).This indicates that substantial variability was present in the linseed accessions selected for study and were suitable for further genetic and selection parameters.

Results of genetic variability parameters indicated that the estimates of PCV value were higher than GCV value. All the traits studied indicating that the apparent variation is not only due to genotypes but, also due to the influence of environment. High values of PCV and GCV were obtained for traits viz., number of primary branches per plant, number of capsules per plant. Moderate PCV and GCV (10-20\%) values for plant height (cm), number of seeds per capsule, 1000 seed weight (g), seed yield per Plant (g). Low PCV and GCV $(<10)$ observed for days to 50 per cent flowering, days to maturity, harvest index $(\%)$, protein content $(\%)$ and oil (\%) (Table-2). Earlier worker Ahmad (2017), Choudhary et al., (2017) and Kaur and Kumar (2018) were supported above findings.

High heritability observed for 1000 seed weight, number of primary branches per plant, capsules per plant, plant height, days to 50 per cent flowering, oil content, harvest index and days to maturity. Similar result was observed by Akbar et al., (2003); Dandigadasar et al., (2011); Choudhary et al., (2017); Ahmed (2017) and Singh et al., (2019). In the present investigation high estimate of heritability coupled with high to moderate genetic advance as per cent of mean was recorded for number of capsules per plant followed by number of primary branches per plant, 1000 seed weight and plant height. This indicates that these characters might be governed by additive gene effects. It was reported by Kanwar et al., (2014); Tiwari and Singh (2014); Tyagi et al., (2014); Singh et al., (2015); Chandrawati et al., (2016); Ashok et al., (2017) and Ahmed (2017). High heritability with low genetic advance as per cent of mean was found for days to maturity.

Correlation coefficient analysis revealed that seed yield per plant exhibited significant and positive correlation both at genotypic and phenotypic level with plant height, number of capsules per plant and 1000 seed weight. Hence, direct selection for these traits would therefore be most effective in the improvement of linseed genotypes (Table 3). Similar results were reported by Ahmad (2017). The association studies indicating that seed yield of linseed can be improved by selecting genotype having higher values for these traits at both genotypic and phenotypic levels. 
Table.1 Analysis of variance for yield and its attributing traits in Linseed genotypes

\begin{tabular}{|c|c|c|c|c|c|c|c|c|c|c|c|c|}
\hline \multirow{2}{*}{$\begin{array}{l}\text { Source of } \\
\text { Variation }\end{array}$} & \multirow{2}{*}{$\begin{array}{l}\text { D. } \\
\text { f. }\end{array}$} & \multicolumn{11}{|c|}{ MEAN SUM OF SQUARES } \\
\hline & & $\begin{array}{c}\text { Days to } \\
50 \% \\
\text { flowering }\end{array}$ & $\begin{array}{l}\text { Days to } \\
\text { maturity }\end{array}$ & $\begin{array}{l}\text { Plant height } \\
\quad \text { (cm) }\end{array}$ & $\begin{array}{c}\text { Number of } \\
\text { primary } \\
\text { branches per } \\
\text { plant }\end{array}$ & $\begin{array}{c}\text { Number of } \\
\text { capsules per } \\
\text { plant }\end{array}$ & $\begin{array}{l}\text { Number of } \\
\text { seeds per } \\
\text { capsule }\end{array}$ & $\begin{array}{l}\text { 1000 Seed } \\
\text { weight }(\mathrm{g})\end{array}$ & $\begin{array}{c}\text { Harvest } \\
\text { index (\%) }\end{array}$ & $\begin{array}{c}\text { Protein } \\
\text { content } \\
(\%)\end{array}$ & $\begin{array}{c}\text { Oil } \\
\text { content } \\
(\%)\end{array}$ & $\begin{array}{c}\text { Seed yield } \\
\text { per Plant } \\
\text { (g) }\end{array}$ \\
\hline Replication & 2 & 0.287 & 0.176 & 8.413 & 0.170 & 81.788 & 0.420 & 0.043 & 1.056 & 0.067 & 0.562 & 0.901 \\
\hline Genotypes & 35 & $39.628 * *$ & $17.920 * *$ & $159.470 * *$ & $5.390 * *$ & $3061.367 * *$ & $2.085^{* *}$ & $1.891 * *$ & $26.745 * *$ & $1.944 * *$ & $13.189 * *$ & $2.228^{* *}$ \\
\hline Error & 70 & 1.611 & 1.938 & 9.326 & 0.089 & 68.129 & 0.476 & 0.016 & 2.378 & 0.565 & 0.605 & 0.336 \\
\hline
\end{tabular}

Table.2 Genetic variability parameters for seed yield and its contributing characters in linseed genotypes

\begin{tabular}{|c|c|c|c|c|c|c|c|c|c|}
\hline \multirow{3}{*}{$\begin{array}{l}\text { S. } \\
\text { NO. }\end{array}$} & \multirow{3}{*}{ Characters } & \multicolumn{8}{|c|}{ Genetic parameters } \\
\hline & & \multirow[t]{2}{*}{ Mean } & \multicolumn{2}{|c|}{ Range } & \multirow[t]{2}{*}{$\operatorname{PCV}(\%)$} & \multirow[t]{2}{*}{$\operatorname{GCV}(\%)$} & \multirow{2}{*}{$\begin{array}{l}\mathbf{h}_{(\mathrm{bs})}^{2} \\
(\%)\end{array}$} & \multirow{2}{*}{$\begin{array}{l}\text { Genetic } \\
\text { advance }\end{array}$} & \multirow{2}{*}{$\begin{array}{c}\text { Genetic advance as } \\
\text { per cent of mean }\end{array}$} \\
\hline & & & Minimum & Maximum & & & & & \\
\hline 1 & Days to $50 \%$ flowering & 68.16 & 61.67 & 77.33 & 5.55 & 5.22 & 88.70 & 6.90 & 10.13 \\
\hline 2 & Days to maturity & 129.23 & 124 & 134 & 2.09 & 1.79 & 73.30 & 4.07 & 3.16 \\
\hline 3 & Plant height (cm) & 58.56 & 42.53 & 76.30 & 13.16 & 12.08 & 84.30 & 13.40 & 22.86 \\
\hline 4 & Number of primary branches per plant & 5.08 & 3.27 & 8.67 & 26.80 & 26.14 & 95.20 & 2.67 & 52.54 \\
\hline 5 & Number of capsules per plant & 101.94 & 46.67 & 174.67 & 32.03 & 30.99 & 93.60 & 62.96 & 61.76 \\
\hline 6 & Number of seeds per capsule & 7.48 & 6.30 & 10.00 & 13.45 & 9.79 & 53.00 & 1.10 & 14.68 \\
\hline 7 & 1000 Seed weight (g) & 7.35 & 5.80 & 8.77 & 10.90 & 10.76 & 97.40 & 1.61 & 21.89 \\
\hline 8 & Harvest Index (\%) & 33.68 & 28.56 & 39.97 & 9.62 & 8.46 & 77.40 & 5.16 & 15.33 \\
\hline 9 & Protein content (\%) & 20.32 & 18.16 & 21.42 & 4.98 & 3.34 & 44.80 & 0.94 & 4.60 \\
\hline 10 & Oil content (\%) & 38.66 & 34.40 & 43.14 & 5.67 & 5.30 & 87.40 & 3.94 & 10.20 \\
\hline 11 & Seed yield per Plant (g) & 6.13 & 4.50 & 7.97 & 16.19 & 13.14 & 65.90 & 1.35 & 21.97 \\
\hline
\end{tabular}


Table.3 Genotypic and phenotypic correlation coefficient between different traits in linseed genotypes

\begin{tabular}{|c|c|c|c|c|c|c|c|c|c|c|c|c|c|}
\hline $\begin{array}{l}\text { Sr. } \\
\text { No. }\end{array}$ & Character & $\mathbf{r}$ & $\begin{array}{c}\text { Days to } 50 \\
\% \\
\text { flowering }\end{array}$ & $\begin{array}{l}\text { Days to } \\
\text { maturity }\end{array}$ & $\begin{array}{c}\text { Plant } \\
\text { height }(\mathrm{cm})\end{array}$ & $\begin{array}{c}\text { Number of } \\
\text { primary } \\
\text { branches per } \\
\text { plant }\end{array}$ & $\begin{array}{c}\text { Number of } \\
\text { capsules per } \\
\text { plant }\end{array}$ & $\begin{array}{c}\text { Number of } \\
\text { seeds per } \\
\text { capsule }\end{array}$ & $\begin{array}{l}1000 \text { seed } \\
\text { weight }(g)\end{array}$ & $\begin{array}{c}\text { Harvest } \\
\text { index }(\%)\end{array}$ & $\begin{array}{c}\text { Protein content } \\
(\%)\end{array}$ & $\begin{array}{l}\text { Oil content } \\
(\%)\end{array}$ & $\begin{array}{c}\text { Seed yield } \\
\text { per plant } \\
(\mathrm{g})\end{array}$ \\
\hline \multirow[t]{2}{*}{1} & \multirow{2}{*}{$\begin{array}{l}\text { Days to } 50 \\
\% \\
\text { flowering }\end{array}$} & $\mathbf{r}_{\mathrm{g}}$ & 1.000 & $0.225^{*}$ & -0.021 & $0.241^{*}$ & -0.038 & -0.110 & $-0.289 * *$ & $-0.255^{* *}$ & -0.021 & 0.173 & -0.094 \\
\hline & & $\mathbf{r}_{p}$ & 1.000 & 0.143 & -0.016 & $0.240 *$ & -0.046 & -0.074 & $-0.261^{*}$ & $-0.207^{*}$ & -0.072 & 0.153 & -0.093 \\
\hline \multirow[t]{2}{*}{2} & \multirow{2}{*}{$\begin{array}{l}\text { Days to } \\
\text { maturity }\end{array}$} & $\mathbf{r}_{\mathrm{g}}$ & & 1.000 & 0.002 & 0.085 & $-0.274 * *$ & $0.263^{*}$ & -0.081 & $-0.393 * *$ & -0.124 & -0.065 & $-0.406^{* *}$ \\
\hline & & $\mathbf{r}_{\mathbf{p}}$ & & 1.000 & -0.072 & 0.052 & $-0.198 *$ & 0.138 & -0.078 & $-0.300 * *$ & -0.060 & -0.055 & $-0.303 * *$ \\
\hline \multirow[t]{2}{*}{3} & \multirow{2}{*}{$\begin{array}{l}\text { Plant } \\
\text { height } \\
\text { (cm) }\end{array}$} & $\mathbf{r}_{\mathrm{g}}$ & & & 1.000 & -0.080 & $0.283^{* *}$ & -0.068 & $0.476^{* *}$ & $0.270 * *$ & 0.059 & -0.124 & $0.280 * *$ \\
\hline & & $\mathbf{r}_{\mathbf{p}}$ & & & 1.000 & -0.059 & $0.235^{*}$ & -0.054 & $0.438 * *$ & $0.231^{*}$ & 0.045 & -0.103 & $0.259 * *$ \\
\hline \multirow[t]{2}{*}{4} & \multirow{2}{*}{$\begin{array}{l}\text { Number of } \\
\text { primary } \\
\text { branches } \\
\text { per plant }\end{array}$} & $\mathbf{r}_{\mathrm{g}}$ & & & & 1.000 & $0.359^{* *}$ & $-0.331 * *$ & $-0.215^{*}$ & 0.022 & 0.035 & $-0.208^{*}$ & -0.089 \\
\hline & & $\mathbf{r}_{p}$ & & & & 1.000 & $0.327 * *$ & $-0.233^{*}$ & $-0.206^{*}$ & 0.002 & -0.012 & $-0.206^{*}$ & -0.088 \\
\hline \multirow[t]{2}{*}{5} & \multirow{2}{*}{$\begin{array}{l}\text { Number of } \\
\text { capsules } \\
\text { per plant }\end{array}$} & $\mathbf{r}_{\mathrm{g}}$ & & & & & 1.000 & $-0.389 * *$ & 0.144 & 0.172 & -0.037 & -0.085 & $0.484 * *$ \\
\hline & & $\mathbf{r}_{p}$ & & & & & 1.000 & $-0.278 * *$ & 0.130 & 0.138 & -0.004 & -0.065 & $0.385^{* *}$ \\
\hline \multirow[t]{2}{*}{6} & \multirow{2}{*}{$\begin{array}{l}\text { Number of } \\
\text { seeds per } \\
\text { capsule }\end{array}$} & $\mathbf{r}_{\mathrm{g}}$ & & & & & & 1.000 & $0.221 *$ & 0.181 & -0.118 & 0.174 & -0.143 \\
\hline & & $\mathbf{r}_{p}$ & & & & & & 1.000 & 0.173 & 0.165 & -0.168 & 0.082 & -0.023 \\
\hline \multirow[t]{2}{*}{7} & \multirow{2}{*}{$\begin{array}{l}1000 \text { seed } \\
\text { weight }(\mathrm{g})\end{array}$} & $\mathbf{r}_{\mathrm{g}}$ & & & & & & & 1.000 & -0.002 & -0.172 & -0.048 & $0.273 * *$ \\
\hline & & $\mathbf{r}_{p}$ & & & & & & & 1.000 & -0.014 & -0.134 & -0.061 & $0.220^{*}$ \\
\hline \multirow[t]{2}{*}{8} & \multirow{2}{*}{$\begin{array}{l}\text { Harvest } \\
\text { index }(\%)\end{array}$} & $\mathbf{r}_{\mathrm{g}}$ & & & & & & & & 1.000 & -0.162 & -0.092 & 0.009 \\
\hline & & $\mathbf{r}_{p}$ & & & & & & & & 1.000 & -0.040 & -0.097 & 0.046 \\
\hline \multirow[t]{2}{*}{9} & \multirow{2}{*}{$\begin{array}{l}\text { Protein } \\
\text { content } \\
(\%)\end{array}$} & $\mathbf{r}_{\mathrm{g}}$ & & & & & & & & & 1.000 & -0.048 & $0.191^{*}$ \\
\hline & & $\mathbf{r}_{\mathbf{p}}$ & & & & & & & & & 1.000 & -0.001 & 0.102 \\
\hline \multirow[t]{2}{*}{10} & \multirow{2}{*}{$\begin{array}{l}\text { Oil content } \\
(\%)\end{array}$} & $\mathbf{r}_{\mathrm{g}}$ & & & & & & & & & & 1.000 & 0.099 \\
\hline & & $\mathbf{r}_{\mathrm{p}}$ & & & & & & & & & & 1.000 & 0.041 \\
\hline \multirow[t]{2}{*}{11} & \multirow{2}{*}{$\begin{array}{l}\text { Seed yield } \\
\text { per plant } \\
\text { (g) }\end{array}$} & $\mathbf{r}_{\mathrm{g}}$ & & & & & & & & & & & 1.000 \\
\hline & & $\mathbf{r}_{p}$ & & & & & & & & & & & 1.000 \\
\hline
\end{tabular}

$* * *=$ Significant at $5 \%$ and $1 \%$ both at genotypic and phenotypic levels, respectively. 
Table.4 Direct (diagonal) and indirect effects of yield components on seed yield per plant at genotypic level in linseed genotypes

\begin{tabular}{|c|c|c|c|c|c|c|c|c|c|c|c|c|c|}
\hline $\begin{array}{l}\text { S. } \\
\text { NO. }\end{array}$ & Character & & $\begin{array}{c}\text { Days to } 50 \% \\
\text { flowering }\end{array}$ & $\begin{array}{l}\text { Days to } \\
\text { maturity }\end{array}$ & $\begin{array}{c}\text { Plant } \\
\text { height } \\
(\mathbf{c m})\end{array}$ & $\begin{array}{c}\text { Number of } \\
\text { primary } \\
\text { branches per } \\
\text { plant }\end{array}$ & $\begin{array}{c}\text { Number of } \\
\text { capsules per } \\
\text { plant }\end{array}$ & $\begin{array}{l}\text { Number of } \\
\text { seeds per } \\
\text { capsule }\end{array}$ & $\begin{array}{l}1000 \text { Seed } \\
\text { weight }(g)\end{array}$ & $\begin{array}{c}\text { Harvest } \\
\text { index }(\%)\end{array}$ & $\begin{array}{c}\text { Protein } \\
\text { content } \\
(\%)\end{array}$ & $\begin{array}{c}\text { Oil } \\
\text { content } \\
(\%)\end{array}$ & $\begin{array}{c}\text { Seed yield } \\
\text { per plant (g) }\end{array}$ \\
\hline 1 & $\begin{array}{l}\text { Days to } 50 \\
\text { flowering }\end{array}$ & G & -0.0040 & -0.0880 & -0.0040 & -0.0320 & -0.0180 & -0.0180 & -0.0090 & 0.0720 & -0.0030 & 0.0120 & -0.094 \\
\hline 2 & $\begin{array}{l}\text { Days to } \\
\text { maturity }\end{array}$ & G & -0.0090 & -0.3940 & 0.0050 & -0.0120 & -0.1330 & 0.0440 & -0.0030 & 0.1116 & -0.0180 & -0.0040 & $-0.406 * *$ \\
\hline 3 & $\begin{array}{l}\text { Plant height } \\
\text { (cm) }\end{array}$ & G & 0.0080 & -0.0090 & 0.2050 & 0.0110 & 0.1380 & -0.0110 & 0.0160 & -0.0770 & 0.0080 & -0.0080 & $0.280 * *$ \\
\hline 4 & $\begin{array}{c}\text { Number of } \\
\text { primary } \\
\text { branches per } \\
\text { plant }\end{array}$ & $\mathbf{G}$ & -0.0010 & -0.0340 & -0.0160 & -0.1350 & 0.1750 & -0.0550 & -0.0070 & -0.0060 & 0.0050 & -0.0140 & -0.089 \\
\hline 5 & $\begin{array}{c}\text { Number of } \\
\text { capsules per } \\
\text { plant }\end{array}$ & G & 0.0020 & 0.1080 & 0.0580 & -0.0480 & 0.4860 & -0.0650 & 0.0050 & -0.0490 & -0.0050 & -0.0060 & $0.484 * *$ \\
\hline 6 & $\begin{array}{c}\text { Number of } \\
\text { seeds per } \\
\text { capsule }\end{array}$ & $\mathbf{G}$ & 0.0004 & -0.1034 & -0.0139 & 0.0445 & -0.1889 & 0.1669 & 0.0072 & -0.0513 & -0.0159 & 0.0116 & -0.143 \\
\hline 7 & $\begin{array}{l}1000 \text { Seed } \\
\text { weight }(\mathrm{g})\end{array}$ & $\mathbf{G}$ & 0.0011 & 0.0320 & 0.0978 & 0.0289 & 0.0698 & 0.0368 & 0.0324 & 0.0005 & -0.0232 & -0.0032 & $0.273 * *$ \\
\hline 8 & $\begin{array}{c}\text { Harvest } \\
\text { index }(\%)\end{array}$ & $\mathbf{G}$ & 0.0010 & 0.1545 & 0.0554 & -0.0030 & 0.0834 & 0.0301 & -0.0001 & -0.2843 & -0.0219 & -0.0061 & 0.009 \\
\hline 9 & $\begin{array}{c}\text { Protein } \\
\text { content }(\%)\end{array}$ & $\mathbf{G}$ & 0.0001 & 0.0487 & 0.0121 & -0.0048 & -0.0180 & -0.0197 & -0.0056 & 0.0461 & 0.1350 & -0.0032 & $0.191^{*}$ \\
\hline 10 & $\begin{array}{l}\text { Oil content } \\
(\%)\end{array}$ & $\mathbf{G}$ & -0.0007 & 0.0254 & -0.0255 & 0.0280 & -0.0414 & 0.0291 & -0.0016 & 0.0261 & -0.0065 & 0.0662 & 0.099 \\
\hline
\end{tabular}

$*, * *=$ Significant at $5 \%$ and $1 \%$ levels, respectively. $\mathrm{G}=$ Genotypic level 
Path coefficient analysis revealed the positive direct effect at genotypic level for the character viz., plant height, number of capsules per plant, number of seeds per capsule, 1000 seed weight, protein content and oil content (Table-4). Similar findings were confirmed by Sahu et al., (2016) reported high direct positive effect of plant height, number of capsules per plant, number of seeds per capsule on seed yield per plant. Choudhary et al., (2016); Ahmed (2017); Kasana et al., (2018) and Ankit et al., (2019) reported direct positive effect of plant height, number of capsules per plant, number of seeds per capsule, 1000 seed weight on seed yield per plant. Hence, desirable improvement may be brought out by selecting genotypes with higher number of capsules per plant, number of seeds per capsule, and 1000 seed weight. However negative direct effect on seed yield was observed in days to 50 per cent flowering, days to maturity and harvest index which is similar finding by Sahu et al., (2016) who reported negative direct effect for these traits.

The indirect effect of days to maturity, harvest index and number of primary branches exerted highest positive indirect via number of seeds per capsule was positive and considerably high effect. All these indirect effects resulted in positive correlation of respective characters with seed yield per plant which is similar to finding of Rajanna et al., (2014); Kasana et al., (2018) who reported indirect effects of days to maturity, harvest index and number of primary branches on seed yield. These characters also showed prominent role as indirect effects on seed yield per plant through most of the component traits. Hence, these traits should be considered as important selection criteria for seed yield improvement.

In conclusion the results of the present investigation the presence of adequate genetic variability within and among the genotypes, which suggests scope for further genetic improvement in linseed. High heritability coupled with high genetic advance were observed for the traits like number of capsules per plant, plant height, number of primary branches per plant and 1000 seed weight with positive direct effect as revealed by phenotypic and genotypic path coefficient making these character desirable for selection. In addition based on correlation and path coefficient analysis study it was inferred that number of capsules per plant had high significant association and also show high positive direct effect on seed yield. Hence, in the improvement programme importance may be given for this trait to improve genetic yield potential in linseed. Therefore, induced genetic variability can be successfully utilized to develop new cultivars of linseed.

\section{Acknowledgement}

The author is thankful to the Guide and committee members of the Department of Genetics and Plant Breeding, Agriculture University, Kota for their untiring help and assistance during the experiment and preparation of manuscript.

\section{References}

Annual Report AIRCP Linseed, (2017-2018). Agriculture statistics at a glance, DAC\&FW, (2018).

Allard RW. Principles of plant breeding. John Willy and Sons, Inc., New York, 1960.

Ahmed, E. (2017). Genetic studies of yield and yield component of Linseed (Linum usitatissimum L.). Journal of Pharmacognosy and Phytochemistry, 1: 872-875.

Ankit, Kherkhi, S.A., Singh, S.P., Singh, V.K., Singh, A. and Tawari, A. (2019).Estimates indirect selection parameters through correlation and path 
analysis in linseed (Linum usitatissimum L.). International Journal of Chemical Studies, 7(1): 2461-2465.

Bindra, S. and Paul S. (2016). Genetic variability and association studies in linseed (Linum usitatissimum L.). The Bioscan, 11(3):1855-1859.

Burton, G.W. and De Vane, E.H. (1953). Estimating heritability in tall fescue (Fistvea arundiancea) from replicated clonal material. Agronomy Journal, 45: 284-291.

Chandrawati, Singh N., Yadav, V.K., Kumar, R., Kumar, S. and Yadav, H.K. (2016).Genetic variability and interrelationship among morphological and yield traits in Linseed (Linum usitatissimum L.).Genetika, 48(3): 881 $-892$

Choudhary, A.K., Marker. S., Rizwi. F.S. (2017). Genetic variability and character association for seed yield in linseed (Linum usitatissimum L.) under rainfed condition. Journal of Pharmacognosy and Phytochemistry, 6(5): 457-460

Choudhary, M., Rahul, V.P, Singh, V. and Chauhan. M.P. (2016). Correlation coefficient and path coefficient analysis for yield and yield related traits in linseed (Linum usitatissimum L.). The Bioscan, 11(2): 939-942.

Dandigadasar, B., Tattirnani, M., Danaraddi. C.S. Shilpa, B.B. and Mohan, R.D. (2011). Genetic variability, correlation and path analysis in linseed. Asian Journal of Biological Sciences, 6: 218222.

Dewy, D.R. and Lu, K.H. (1959). A correlation and path coefficient analysis of components of crested wheat grass seed production. Journal of Agronomy, 51: 515-518.

Gill KS. Linseed. ICAR, New Delhi, (1987)

Fisher, R.A. (1918). The correlation between relatives on the supposition of
Mendelian inheritance. Transactions of the Royal Society Edinburg, 52

Johnson, H. W., Robinson, H.F. and Comstock, R.E. (1955). Estimate of genetic and environmental variability in soybean. Agronomy Journal. 47(7): 314-318.

Kaur, V. Kumar. S., Yadav. R., Wankhede. D.P., Arvind. J., Radhamani. J., Rana, J.C and Kumar.A. (2018). Genetic diversity in Indian and exotic linseed germplasm and identification of traits specific superior accessions. Journal of Environment Biology, 39: 702-709.

Kanwar, R. R., Saxena, R.R. and Ruth, E.E. (2014). Variability, heritability and genetic advance for yield and some yield related traits in linseed (Linum usitatissimum L.). Agricultural Science Digest, 34(2): 154-156.

Kasana, R.K., Singh, P.K., Tomar, A., Mohan, S. and Kumar, S. (2018). Selection parameters (heritability, genetic advance, correlation and path coefficient) analysis in linseed (Linum usitatissimum L.). The Pharma Innovation Journal, 7(6): 16-19.

Leelaathi, T.M., Mogli, S. (2018). Genetic variability, character association and path analysis for yield and yield components in mutant population of linseed. Journal of farm sciences, 31(1): 17-20

Vavilov, N.I. (1935). Studies on the origin of cultivated plants. Bulletin of Botany and Plant Breeding, 16: 39-145.

Panse, V., G. and Sukhatme, P.V. (1985). Statistical methods for agricultural workers, ICAR Publications. New Delhi, 270-274.

Rajanna, B., Biradar, S.A. and Ajithkumar, K. (2014). Correlation and path analysis in linseed. The bioscan, 9(4): 1625-1628, (Supplement on Genetics and Plant Breeding).

Singh, V.K., Kerkhi, SA., Singh, S., P. and 
Tomar, P. (2019) Genetic variability, heritability and genetic advance for grain yield and yield component traits (Linum usitatissimum L.). Journal of Pharmacognosy and Phytochemistry, 8(2): 761-765.

Sahu, G., Mishra, S.P., Mishra, V.K., Sahu, T. and Solanki, R.S. (2016). Correlation and path coefficient analysis in linseed (Linum usitatissimum L.) genotypes under rainfed condition. Environment and Ecology, 34(1A): 288-291.

Wright, S. (1921). Correlation and causation. Journal of Agriculture Research, 257287.

\section{How to cite this article:}

Ashok Kumar Meena, Sandhya Kulhari, Manoj Kumar, N. R. Koli, Yamini Tak, Deepak Meena and Neetu Meena. 2020. Studies on Genetic Variability and Character Association in Linseed (Linum usitatissimum L.) Genotypes. Int.J.Curr.Microbiol.App.Sci. 9(07): 3949-3957. doi: https://doi.org/10.20546/ijcmas.2020.907.464 